\title{
Development of microsatellite markers of vandaceous orchids for species and variety identification
}

\author{
S. Peyachoknagul ${ }^{1,2}$, C. Nettuwakul ${ }^{3}$, P. Phuekvilai ${ }^{1,4}$, S. Wannapinpong ${ }^{1,5}$ \\ and K. Srikulnath ${ }^{1,2}$ \\ ${ }^{1}$ Department of Genetics, Faculty of Science, Kasetsart University, \\ Bangkok, Thailand \\ ${ }^{2}$ Center for Advanced Studies in Tropical Natural Resources, \\ National Research University-Kasetsart University, \\ Bangkok, Thailand \\ ${ }^{3}$ Division of Molecular Medicine, Department of Research and Development, \\ Faculty of Medicine Siriraj Hospital, Mahidol University, Bangkok, Thailand \\ ${ }^{4}$ Department of Biology, Faculty of Science, Silpakorn University, \\ Nakhon Pathom, Thailand \\ ${ }^{5}$ Institute of Food Research and Product Development, Kasetsart University, \\ Bangkok, Thailand
}

Corresponding author: S. Peyachoknagul

E-mail: fscisrp@ku.ac.th

Genet. Mol. Res. 13 (3): 5441-5445 (2014)

Received June 6, 2013

Accepted October 3, 2013

Published July 24, 2014

DOI http://dx.doi.org/10.4238/2014.July.24.23

\begin{abstract}
Vandaceous orchids are a group of orchid genera in the subfamily Vandoideae. Among this group, Mokara, Phalaenopsis, and Vanda are the most popular and commercially important orchids in Thailand. Novel microsatellite markers were developed from Mokara, the intergeneric hybrid from 3 genera Vanda, Ascocentrum, and Arachnis by using enriched method. Six primers from this study plus one primer previously developed from Vanda genome, a total of 7 markers, were selected to characterize 4 orchid genera (Mokara, Vanda, Rhynchostylis,
\end{abstract}


and Ascocenda). The observed and expected heterozygosities varied in the 4 genera from $0.0000-1.0000$ and $0.0000-0.8765$, respectively. The transferability of these primers was also investigated in 76 vandaceous orchids from 12 genera. Three primer pairs, MOK26, MOK29, and MOK62, could successfully amplify the DNA of all samples, while MOK103 could be used with most of the samples. The total number of alleles from 76 samples ranged from 3 to 19 alleles per locus, with an average of 8.5714. Therefore, these markers could be used for variety/ species identification, certification and protection, genetic diversity, and evolutionary studies.

Key words: Microsatellite markers; SSR markers; Vandaceous orchids; Orchid identification

\section{INTRODUCTION}

In Thailand, orchids (family Orchidaceae) are the major ornamental crops as cut flowers and potted plants with export value of about US\$80 million a year. Vandaceous orchids (subfamily Vandoideae), including many genera such as Mokara, Phalaenopsis, Vanda, Aranda, Arachnis, and Ascocentrum, are the second most popular orchids that have high demand in both local and international markets (Lekawatana, 2010). They can be crossed within the same genus or with different genera, leading to the production of various new hybrids having similar morphologies, making it difficult to identify orchid species or hybrids only based on morphological traits. Thus, an alternative identification method for vandaceous orchids is needed for variety and species certification and protection purposes.

Microsatellite or simple sequence repeat (SSR) markers have been used with various applications because they are specific single locus markers, multi-allelic, and co-dominantly inherited (Powell et al., 1996). However, vandaceous orchid-specific microsatellite markers have not yet been developed for the identification and assessment of genetic diversity of orchids. In this study, novel microsatellite markers were developed from Mokara orchid, an intergeneric hybrid from 3 genera, Vanda, Ascocentrum, and Arachnis. These SSR markers (6 from Mokara and 1 from Vanda) were successfully used for variety and species identification of Mokara and could also be transferred to other genera of vandaceous orchids.

\section{MATERIAL AND METHODS}

Genomic DNA of Mokara cultivar Golden Tommy 'Salaya Gold' was isolated for the development of microsatellite libraries. Two DNA libraries enriched for di- and trinucleotide repeats were constructed following Yaish and Pérez de la Vega (2003), with slight modification. Briefly, the genomic DNA was digested with MseI, followed by ligation to MseI adapter. The adapter-ligated DNA fragments were then amplified by polymerase chain reaction (PCR) by using the M1 primer (5'-GACGATGAGTCCTGAG-3'). PCR products were subsequently hybridized to biotinylated $(\mathrm{CA})_{15},(\mathrm{GA})_{15}$ and $(\mathrm{CCT})_{10},(\mathrm{ACC})_{10}$ probes and were captured using streptavidin-coated magnetic beads (Dynabeads ${ }^{\circledR}$ Myone $^{\mathrm{TM}}$ Streptavidin C1; Invitrogen, Life Technologies). The di- and trinucleotide-enriched DNAs were eluted, PCR-amplified, cloned 
into pGEM-T vector (Promega, USA), and transformed into Escherichia coli DH5a competent cells. Of the 340 clones, 264 or $77.65 \%$ were confirmed for the presence of microsatellite sequences by dot-blot hybridization using the SSR probes with a North2South ${ }^{\circledR}$ Chemiluminescent Hybridization and Detection Kit (PIERCE, USA). Of these, 100 positive clones were randomly selected for sequencing at Macrogen Sequencing Service (Macrogen, Inc., Seoul, South Korea). The obtained microsatellite sequences were categorized as dinucleotide, trinucleotide, and compound repeats as follows: 20 clones with $(\mathrm{CA})_{n}, 34$ clones with $(\mathrm{GA})_{\mathrm{n}}, 1$ clone with (ACC), 29 clones with $(\mathrm{CCT})_{\mathrm{n}}, 7$ clones with $(\mathrm{GA})_{\mathrm{n}}$ and $(\mathrm{CCT})_{\mathrm{n}}, 4$ clones with $(\mathrm{CA})_{\mathrm{n}}$ and $(\mathrm{GA})_{\mathrm{n}}$ repeats; and 5 clones with no microsatellite sequence. Thirty specific PCR primers were designed based on sufficient flanking regions by using the Primer3 program (Rozen and Skaletsky, 2000). Six primers (MOK26, MOK29, MOK62, MOK102, MOK103, and MOK107) plus 1 primer (C106) previously developed from Vanda orchid (Phuekvilai et al., 2009) were selected based on the ability to produce readable and polymorphic band patterns. The sequences of all DNA clones used for primer designing were submitted to GenBank (http://www.ncbi.nlm.nih.gov; Table 1).

Table 1. Characteristics of microsatellite marker loci: locus name, GenBank accession number, primer sequences, repeat motif, annealing temperature (Ta), and size range of PCR products.

\begin{tabular}{|c|c|c|c|c|c|}
\hline Locus & Accession No. & Primer sequence (5' to $\left.3^{\prime}\right)$ & Repeat & $\mathrm{Ta}$ & Size range \\
\hline MOK26 & FJ539056 & $\begin{array}{l}\text { F: AGAATGAGGGAGGTATAGGG } \\
\text { R: TGCCTTGGATGTGCGTTCG }\end{array}$ & $(\mathrm{AGG})_{17}$ & 52 & $210-280$ \\
\hline MOK29 & FJ539057 & $\begin{array}{l}\text { F: TTCAGCGTTTCCATGTCGAAG } \\
\text { R: AGTAAAGCCGCCATCTTGG }\end{array}$ & $(\mathrm{GA})_{13}$ & 52 & $130-190$ \\
\hline MOK62 & FJ539058 & $\begin{array}{l}\text { F: AGAGTGAAGAGAGTGTTGG } \\
\text { R: GGACTGTAAACTTCATGAGC }\end{array}$ & $(\mathrm{GA})_{18}$ & 52 & $140-165$ \\
\hline MOK102 & FJ539059 & $\begin{array}{l}\text { F: AGAATGCCACAATATCATCACC } \\
\text { R: CTGTGTCTGTTTCTATTTATGTG }\end{array}$ & $(\mathrm{CA})_{27}$ & 48 & $110-135$ \\
\hline MOK103 & FJ539060 & $\begin{array}{l}\text { F: TCTAGACATGTTTGAGAGGTGC } \\
\text { R: TTACTCTTCCACTCTTCCATCC }\end{array}$ & $(\mathrm{GA})_{34}$ & 50 & $160-198$ \\
\hline MOK107 & FJ539061 & $\begin{array}{l}\text { F: CGCCCAACGAATAGAATGTTGG } \\
\text { R: ACTATCTTCCTTACTCTTGCCCTC }\end{array}$ & $(\mathrm{GA})_{22}$ & 56 & $120-160$ \\
\hline C106 & FJ539051 & $\begin{array}{l}\text { F: AAGTCTAGCTTTTGGTTGAGG } \\
\text { R: ATCGATGGTTTGTTCTTCTAGC }\end{array}$ & $(\mathrm{TA})_{5}(\mathrm{GT})_{45}(\mathrm{GA})_{25}$ & 44 & $185-210$ \\
\hline
\end{tabular}

The selected PCR primers were used for DNA amplification of 76 vandaceous orchid samples. The total volume of each PCR mixture was $20 \mu \mathrm{L}$, consisting of $50 \mathrm{ng}$ genomic DNA, 1X PCR buffer, $1.5 \mathrm{mM} \mathrm{MgCl}, 5 \mu \mathrm{M}$ of each primer, $0.2 \mathrm{mM}$ dNTP, and $0.5 \mathrm{U}$ Taq DNA polymerase (Invitrogen, Carlsbad, CA, USA). The PCR cycling condition was $94^{\circ} \mathrm{C}$ for $3 \mathrm{~min}$, followed by 35 cycles of $94^{\circ} \mathrm{C}$ for $30 \mathrm{~s}$, annealing temperature (depending on the primer) for 1 min, and $72^{\circ} \mathrm{C}$ for $30 \mathrm{~s}$, and a final extension of $72^{\circ} \mathrm{C}$ for $5 \mathrm{~min}$. The PCR products were then run on $6 \%(\mathrm{w} / \mathrm{v})$ denaturing polyacrylamide gel and visualized by silver staining as described previously (Benbouza et al., 2006). For each microsatellite locus, allele sizes were estimated by comparison with standard-sized DNA markers (25-bp DNA Ladder; Invitrogen). All parameters were measured using 4 orchid genera having the sample number equal to or greater than 5 samples. The number of alleles $\left(N_{\mathrm{A}}\right)$ was counted for each locus, and the observed heterozygosity $\left(H_{\mathrm{O}}\right)$ and expected heterozygosity $\left(H_{\mathrm{E}}\right)$ were estimated following Nei and $\mathrm{Li}(1979)$.

\section{RESULTS AND DISCUSSION}

After optimization of PCR with some samples of Mokara and Vanda, 7 primer pairs 
were selected to evaluate the polymorphism and discriminating potential of each primer in 3 parental genera, Mokara, Vanda, and Ascocenda and another non-parental genus, Rhynchostylis. The results showed that the $N_{\mathrm{A}}$ ranged from 2-7, 1-6, 2-13, and 1-4 in Mokara, Vanda, Rhynchostylis, and Ascocenda, with an average of 4.57, 3.43, 5.80, and 2.86 alleles per locus, respectively. The $H_{\mathrm{O}}$ for individual locus ranged from 0.1111-1.0000 (average, 0.6349) in Mokara, 0.0000-0.9285 (average, 0.5119) in Vanda, 0.1111-0.9091 (average, 0.6004) in Rhynchostylis, and 0.0000-1.0000 (average, 0.7333) in Ascocenda. The $H_{\mathrm{E}}$ ranged from 0.1512-0.7054 (average, 0.5159), 0.0000-0.6625 (average, 0.4308), 0.2822-0.8765 (average, 0.6118), and 0.0000-0.7000 (average of 0.5447) in Mokara, Vanda, Rhynchostylis, and Ascocenda, respectively (Table 2).

Table 2. Number of samples used from each genus and the number which can be amplified with the primers in parenthesis, number of alleles $\left(N_{\mathrm{A}}\right)$, observed heterozygosity $\left(H_{\mathrm{O}}\right)$ and expected heterozygosity $\left(H_{\mathrm{E}}\right)$ in four genera.

\begin{tabular}{|c|c|c|c|c|c|c|c|c|c|}
\hline \multirow[t]{2}{*}{ Orchid genus } & \multirow[t]{2}{*}{ Number } & \multicolumn{7}{|c|}{ Number of samples which can be amplified with each primer } & \multirow[t]{2}{*}{ Average } \\
\hline & & MOK26 & MOK29 & MOK62 & MOK102 & MOK103 & MOK107 & $\mathrm{C} 106$ & \\
\hline Mokara & 27 & (27) & (27) & (27) & (27) & (27) & (27) & (27) & \\
\hline$N_{\mathrm{A}}$ & & 2 & 7 & 4 & 3 & 4 & 7 & 5 & 4.57 \\
\hline$H_{\mathrm{O}}^{\mathrm{A}}$ & & 0.3333 & 0.9629 & 0.1111 & 0.9629 & 1.0000 & 0.7778 & 0.2963 & 0.6349 \\
\hline$H_{\mathrm{E}}$ & & 0.4032 & 0.6974 & 0.1512 & 0.6238 & 0.7054 & 0.6537 & 0.3766 & 0.5159 \\
\hline Vanda & 14 & $(14)$ & (14) & (14) & (11) & (14) & (14) & (14) & \\
\hline$N_{\mathrm{A}}$ & & 6 & 3 & 4 & 1 & 3 & 4 & 3 & 3.43 \\
\hline$H_{\mathrm{O}}^{\mathrm{A}}$ & & 0.9285 & 0.3571 & 0.2143 & - & 0.7857 & 0.7143 & 0.0714 & $0.5119^{*}$ \\
\hline$H_{\mathrm{E}}$ & & 0.6625 & 0.3064 & 0.2031 & - & 0.5214 & 0.6276 & 0.2638 & $0.4308^{*}$ \\
\hline Rhynchostylis & 11 & (11) & (11) & (11) & (9) & (10) & $(0)$ & (0) & \\
\hline$N_{\mathrm{A}}$ & & 6 & 13 & 2 & 2 & 6 & - & - & 5.80 \\
\hline$H_{\mathrm{O}}^{\mathrm{A}}$ & & 0.4545 & 0.9091 & 0.7273 & 0.1111 & 0.8000 & - & - & 0.6004 \\
\hline$H_{\mathrm{E}}^{\mathrm{O}}$ & & 0.6602 & 0.8765 & 0.4608 & 0.2822 & 0.7794 & - & - & 0.6118 \\
\hline Ascocenda & 5 & (5) & (5) & (5) & $(5)$ & (5) & (5) & (5) & \\
\hline$N_{\mathrm{A}}$ & & 4 & 2 & 1 & 2 & 4 & 3 & 4 & 2.86 \\
\hline$H_{\mathrm{O}}^{\mathrm{A}}$ & & 0.8000 & 0.4000 & - & 0.4000 & 1.0000 & 0.8000 & 1.0000 & $0.7333 *$ \\
\hline$H_{\mathrm{E}}$ & & 0.7000 & 0.3200 & - & 0.3200 & 0.6517 & 0.5922 & 0.6841 & $0.5447 *$ \\
\hline Ascocentrum & 4 & (4) & (4) & (4) & (4) & (4) & (4) & (4) & \\
\hline Aranda & 3 & (3) & (3) & (3) & (3) & (3) & (3) & (3) & \\
\hline Vanda (terete-leaf) & 2 & (2) & (2) & (2) & (0) & (2) & (0) & (2) & \\
\hline Phalaenopsis & 2 & (2) & (2) & (2) & (0) & (2) & $(0)$ & $(0)$ & \\
\hline Kagawara & 2 & (2) & (2) & (2) & (2) & (2) & (2) & (2) & \\
\hline Renanstylis & 2 & (2) & (2) & (2) & (2) & (2) & (2) & (2) & \\
\hline Rhynchovanda & 2 & (2) & (2) & (2) & (2) & (2) & (2) & (2) & \\
\hline Rhynchorides & 1 & (1) & (1) & (1) & (1) & (1) & (1) & $(0)$ & \\
\hline Arachnostylis x Ascocenda & 1 & (1) & (1) & (1) & (1) & (1) & (1) & (1) & \\
\hline Total number & 76 & (76) & (76) & (76) & (67) & (75) & (61) & (63) & \\
\hline Total $N$ & & 11 & 19 & 6 & 3 & 7 & 9 & 5 & 8.5714 \\
\hline
\end{tabular}

*The average $H_{\mathrm{O}}$ and $H_{\mathrm{E}}$ are calculated from six loci excluding the locus having only one allele.

Generally, the limitation of microsatellite markers is their specificity to the species from which they were developed and can be used only in closely related species (Clauss et al., 2002; Baruah et al., 2003). To expand their transferability to several vandaceous orchids, we developed microsatellite markers from Mokara, an intergeneric hybrid, whose genetic background is derived from 3 genera, Vanda, Ascocentrum, and Arachnis. DNA samples from 12 orchid genera were tested, and the total number of allele (Total $N_{\mathrm{A}}$ ) was found to range from 3 to 19 , with an average of 8.5714 alleles per locus. Three primer pairs, MOK26, MOK29, and MOK62, could successfully amplify the DNA of all samples from 12 genera, namely, Mokara, Vanda, Rhynchostylis, Ascocenda, Ascocentrum, Aranda, Kagawara, Phalaenopsis, 
Rhynchovanda, Renanstylis, Rhynchorides, and a hybrid between Arachnostylis x Ascocenda. The primer MOK103 could be used with most individuals except one sample of Rhynchostylis (Table 2), suggesting that the deletion of the microsatellite region or the mutation in the flanking region might have occurred in this Rhynchostylis sample (Callen et al., 1993; Lehmann et al., 1996). However, MOK102 and MOK107 could only amplify the DNA of some genera but not those of Rhynchostylis, Phalaenopsis, and terete-leaf Vanda (Vanda teres and V. Miss Joaquim). These results imply that these 3 genera are probably less related to other genera in this subfamily. C106 could not amplify the DNA from Rhynchostylis and Phalaenopsis, but could amplify DNA from the 2 terete-leaf Vanda (Table 2), which might be because of its development from Vanda orchid. Even though terete-leaf Vanda has now been separated from this genus and considered to be a new genus, its genetic background might be closely related.

To our knowledge, this is the first report on SSR markers having the highest transferability among 12 orchid genera. These markers could become a powerful tool in identifying vandaceous orchids, evaluating purity in commercial samples, and assessing genetic diversity and conservation study.

\section{ACKNOWLEDGMENTS}

Research supported by the National Research Council of Thailand. Special thanks are extended to Jitrapan Piluek, Department of Horticulture, Faculty of Agriculture, Kasetsart University, for providing the orchid samples and Amara Thongpan for her suggestions in the preparation of this manuscript.

\section{REFERENCES}

Baruah A, Naik V, Hendre PS, Rajkumar R, et al. (2003). Isolation and characterization of nine microsatellites markers from Coffea arabica L., showing wide cross-species amplification . Mol. Ecol. Notes 3: 647-650.

Benbouza H, Jacquemin JM, Baudin JP and Mergeai G (2006). Optimization of a reliable, fast, cheap and sensitive silver staining method to detect SSR markers in polyacrylamide gels. Biotechnol. Agron. Soc. Environ. 10: 77-81.

Callen DF, Thompson AD, Shen Y, Phillips HA, et al. (1993). Incidence and origin of "null" alleles in the (AC) microsatellite markers. Am. J. Hum. Genet. 52: 922-927.

Clauss MJ, Cobban H and Mitchell-Olds T (2002). Cross-species microsatellite markers for elucidating population genetic structure in Arabidopsis and Arabis (Brassicaceae). Mol. Ecol. 11: 591-601.

Lehmann T, Hawley WA and Collins FH (1996). An evaluation of evolutionary constraints on microsatellite loci using null alleles. Genetics 144: 1155-1163.

Lekawatana S (2010). Thai Orchid: Current Situation. In: Taiwan International Orchid Symposium, March 5, 2010, International Conference Hall, Taiwan Orchid Plantation, Tainan, Taiwan.

Nei M and Li WH (1979). Mathematical model for studying genetic variation in terms of restriction endonucleases. Proc. Natl. Acad. Sci. U. S. A. 76: 5269-5273.

Phuekvilai P, Pongtongkam P and Peyachoknagul S (2009). Development of microsatellite markers for Vanda orchid. Kasetsart J. (Nat. Sci.) 43: 497-506.

Powell W, Machray GC and Provan J (1996). Polymorphism revealed by simple sequence repeats. Trends Plant Sci. 1: 215-222.

Rozen S and Skaletsky HJ (2000). Primer3 on the WWW for General Users and for Biologist Programmers. In: Bioinformatics Methods and Protocols: Methods in Molecular Biology (Krawetz S and Misener S, eds.). Humana Press, Totowa.

Yaish MWF and Pérez de la Vega M (2003). Isolation of (GA) microsatellite sequences and description of a predicted MADS-box sequence isolated from common bean (Phaseolus vulgaris L.). Genet. Mol. Biol. 3: 337-342. 